\title{
The Urgency of Regional Regulation Bill of Serdang Bedagai Regency on Trading Business
}

DOI: https://doi.org/10.47175/rissj.v1i3.105

\section{| Ramlan ${ }^{1, *}$ | Eka NAM Sihombing ${ }^{2}$ | Fajriawati ${ }^{3}$ |}

1,2,3 Faculty of Law, Universitas Muhammadiyah Sumatera Utara, Indonesia

${ }^{*}$ Corresponding Email: ramlan@umsu.ac.id

\begin{abstract}
This study aims to discuss the urgency of regional regulation bill of serdang bedagai regency on trading business. Various problems regulated in this regulation include: The quality that is owned between modern retail and traditional retail is not comparable in terms of capital, management to human resources; The increasing number of modern retailers has made it difficult for traditional retailers to develop because they have to deal directly with modern retailers with better quality; There are no strict sanctions against retailers who violate the relevant provisions; Unilateral determination of the types, sizes and prices of trading terms to retail; and The incomplete application of regulations and criminal provisions whose content is not yet optimal. Currently, the gap between modern trading businesses and traditional trading businesses lies in the distribution chain that is digitally integrated in modern trading businesses, creating synergies among its users. Meanwhile, traditional trading business entrepreneurs are usually cash based and have limited integration with suppliers or banks to manage purchases, supplies and payments. Based on this condition, it is very necessary to form a regulation to create a balanced competition between traditional trading businesses and modern trading businesses, regulations that are able to bring justice to all entrepreneurs, not only provide protection for traditional trading businesses and forget about modern trading businesses that also have a very positive impact on the existence of the regional and national economy or vice versa. The regulation is in the form of a Trade Business Regional Regulation. Regional Regulation Bill of Serdang Bedagai Regency on Trading Business KEYWORDS

Regional Regulation; Serdang Bedagai Regency; trading business
\end{abstract}

\section{INTRODUCTION}

Economic growth and regional development will be influenced by several systems of activity, one of which is trade. One indicator of the level of progress in the economic sector is seen from the frequency of activities in the trade sector and this is directly proportional to the level of welfare in the region. People's welfare is the goal of the functioning of a country and in Indonesia this is stated in the Preamble to the 1945 Constitution of the Republic of Indonesia (UUD NKRI 1945), without the goal of welfare for the entire community in it, the direction of development of a country can be predicted to be prone to abuse by certain parties whose aim is to monopolize welfare for themselves, their groups, or certain circles in their network. 
Regional economic resources are one of the assets most vulnerable to being undermined by these actors, especially in the context of the era of free trade. In this era, various levels of businessmen take advantage of the space provided by local governments to seek profit. Inside, there are micro and small business actors with various small businesses that fill the so-called informal sector and medium and large business actors who fill the formal sector. In the free market domain, a perfect competitive environment for every business actor and high buyer / consumer sovereignty can create price stability and comfort in doing business.

But in reality, the full competition that is expected to occur is not always in line with the above expectations. Even the sovereignty of the buyers is not entirely created because of the weak access of consumers to monitor the various products that are marketed. As a result, prices are unstable and competition becomes unhealthy. The main victims in this unfair environment are the small and micro economic actors or the informal sector.

To get out of this dilemma, a strict rule is needed to arrange for the competition to take place fairly and not in a perfect competition frame where all actors are considered equal to fight each other. It is clear in this thinking that it is impossible for small and even micro business actors to compete with giant business actors who have almost unlimited capital due to the ease of access to banks and the various collateral they have.

The phenomenon of globalization cannot be stopped. Likewise changes in consumer behavior and habits in shopping. However, in recent years the retail sector expansion has tended to go too far. In the retail sector so far, the law of the jungle applies. Who is strong he wins, without an intermediary referee. As the retail giant grows as a major threat to traditional urban markets, the rules of distance, zoning and boundaries are no longer recognized. Even the existence of traditional markets coincides with modern markets.

Internal causes for the sluggishness of traditional shops and markets should be examined and solutions sought without blaming other parties. Because almost all traditional markets in Indonesia are still held on internal market problems such as poor market management, very minimal market facilities and infrastructure, the proliferation of street vendors that reduce market traders' customers and the lack of capital assistance available to traditional traders. We can learn from the success of modern markets. Local governments must also strictly enforce the stipulated regulations so as not to confuse the public, especially business actors.

In the practice of state administration, the government as the state authority has made efforts to rebalance the business competition system in the retail sector as a breath of national economic democracy. One of them is by issuing Regulation of the Minister of Trade Number 70 of 2013 concerning Guidelines for the Arrangement and Development of Traditional Markets, Shopping Centers and Modern Stores. The regulation attempts to establish a legal instrument that has implications for the development of small and medium scale retail trade businesses as well as modern large-scale retail trading businesses. In other words, traditional markets need to be empowered so that they can grow and develop harmoniously, need each other, mutually reinforce and benefit each other.

Various problems regulated in this regulation include: The quality that is owned between modern retail and traditional retail is not comparable in terms of capital, management to human resources; The increasing number of modern retailers has made it difficult for traditional retailers to develop because they have to deal directly with modern retailers with better quality; There are no strict sanctions against retailers who violate the relevant provisions; Unilateral determination of the types, sizes and prices of trading terms to retail; and The incomplete application of regulations and criminal provisions whose content is not yet optimal. 
Based on the aforementioned problems, then the regions should require provisions that can regulate, control, supervise and foster the growth and various trade business activities, healthy and balanced business competition in the trading business in Serdang Bedagai Regency. These provisions are contained in the Regional Regulation Bill of Serdang Bedagai Regency on Trading Business to complement the existing regulations.

Thus, the establishment of a Regional Regulation Bill of Serdang Bedagai Regency on Trading Business is needed in structuring, fostering and safeguarding the Trade Business so that it grows conducive, useful, harmonious, fair and has legal certainty for all members of the community.

\section{REVIEW OF LITERATURE}

\section{Theory of Social Justice According to Pancasila}

Indonesia as a state based on social justice must recognize and protect human rights, which are stated in the 1945 Constitution of the Republic of Indonesia. These rights are contained in Article 27 paragraph (1) and (2), Article 28, Article 29 paragraph (2), and Article 31 paragraph (1). These rights should be properly preserved and thoroughly maintained.

Thus, as a country that is just, the state has the obligation to protect the human rights of its citizens according to human nature who live with comprehensive rights that are always attached to it, on the other hand, citizens are obliged to obey laws and regulations as a manifestation of legal justice in living together as one. a unity with an economic culture based on kinship. Through a well-established collaboration between the various constituent elements of the state, it is hoped that a country with clear and directed goals can be born, including in protecting the interests of various trading business actors.

\section{Legal System Theory}

\section{Legal Substance}

The substance of the law or the substantial system determines whether the law can be implemented or not. Substance also means products produced by people who are in the legal system which includes the decisions they issue and the new rules they draft. The substance also includes living law, not just rules contained in law books. Indonesia as a country that still adheres to the Civil Law System or the Continental European system (although some laws and regulations have also adopted the Common Law System or Anglo Saxon), it is said that law is written regulations while unwritten regulations are not declared law. This system affects the legal system in Indonesia.

\section{Legal Structure / Legal Institution}

In Lawrence Meir Friedman's Theory, this is referred to as a structural system that determines whether or not the law is properly implemented. The legal structure based on Law Number 8 of 1981 includes; starting from the Police, Attorney General's Office, Courts and Criminal Management Bodies. The authority of law enforcement agencies is guaranteed by law so that in carrying out their duties and responsibilities, they are independent from the influence of government power and other influences. There is an adage that states "fiat justitia et pereat mundus" (even though the world is collapsing the law must be enforced). The law cannot be enforced or enforced if there are no credible, competent and independent law enforcement officers. How good is a statutory regulation if it is not supported by good law enforcement officers, then justice is just wishful thinking. 


\section{Legal Culture}

Legal culture is a human attitude towards the law and the legal system of beliefs, values, thoughts, and hopes. Legal culture is an atmosphere of social thought and social forces that determine how law is used, avoided, or abused. Legal culture is closely related to the legal awareness of society. The higher the community's legal awareness, a good legal culture will be created and can change the public's mindset about law so far. In simple terms, the level of community compliance with the law is one indicator of the functioning of the law. Both the legal substance, legal structure and legal culture are interrelated with one another and cannot be separated. In its implementation, the relationship between the three must create mutually supportive relationships in order to create a safe, orderly, peaceful and peaceful lifestyle.

\section{Economic Growth Theory}

Adam Smith was the first father of economics who paid a lot of attention to the problem of economic growth. This is found in his book entitled An Inquiry into the Nature and Cause off the Wealth of Nations (1776) which describes the process of systematic economic growth in the long run. There are two main aspects of economic growth, namely:

\section{Total Output Growth}

There are several main elements in a country, including:

a. Available natural resources (land production factors).

b. Human resources (population).

c. Existing stock of capital goods.

The available natural resources are the basic container for the production activities of a society. The amount of resources available is a "maximum limit" for the growth of an economy. This means that if these resources are not fully utilized, the population and capital stock will play an important role in output growth. But the output growth will stop when all these natural resources are fully utilized. Human resources (population) have a passive role in the process of output growth, meaning that the population will adapt to the needs of labor in society.

\section{The Second Supporting Factor is an Adequate Level of Profit}

This level of profit is closely related to the market area. If the market does not grow as fast as capital grows, the rate of profit will immediately decline, and in the end it will reduce the enthusiasm of the owners of capital to accumulate capital, in the long run the rate of profit will decrease and will eventually reach the minimum level of profit in the stationary position of the economy.

\section{Population Growth}

According to Adam Smith, the population will increase if the prevailing wage rate is higher than the sub-system wage level, namely the level of wages that are mediocre for living. If the wage rate is above the subsystem level, then people will marry at a young age, the mortality rate will decrease, and the number of births will continue to increase. On the other hand, if the prevailing wage rate is lower than the subsystem wage rate, the population will decrease.

\section{Community Covenant Theory}

Immanuel Kant (1724-1804) was a follower of the Community Agreement theory because according to him everyone was free and equal from birth. So Kant stated that the goal of 
the state is to protect and guarantee legal order so that the rights and freedoms of citizens are maintained and preserved. For this reason, a law is needed which is the embodiment of the public will, and therefore must be obeyed by anyone, the people or the government. Kant's critical thinking which can foster the development of the country establishes the conditions for future critical theorists and for contemporary international relations scholars. The three fields are knowledge, morality and politics.

\section{Local Government}

The fourth paragraph of the 1945 Constitution of the Republic of Indonesia states that in order to form a government of the Indonesian State that protects the entire Indonesian nation and all Indonesian blood and to promote public welfare, educate the nation's life, and participate in implementing public order, educating the nation's life, and participate in implementing world order based on independence, eternal peace and social justice, then the national independence of Indonesia is compiled in the Constitution of the Republic of Indonesia.

This fourth paragraph animates Article 18 paragraph (5) of the 1945 Constitution of the Republic of Indonesia which states as follows:

The Regional Government exercises the widest possible autonomy, except for governmental affairs which are determined by law as the affairs of the central government.

Then as a follow-up to Article 18 paragraph (5) of the 1945 Constitution of the Republic of Indonesia, a law that regulates regional government was formed, where the law that governs regional governance that has been in effect until now is Law No. 23 of 2014 concerning Regional Government as amended several times, the latest by Law Number 9 of 2015 concerning Second Amendment to Law Number 23 of 2014 concerning Regional Government.

The law states that regional autonomy is the right, authority and obligation of the autonomous region to regulate and manage government affairs and the interests of local communities in accordance with statutory regulations.

\section{RESULT AND DISCUSSION}

\section{The Evaluation and Analysis of Related Laws and Regulations}

There are several related laws and regulations governing trading business. Some of them will be discussed in this chapter, including:

\section{The 1945 Constitution of the Republic of Indonesia}

The 1945 Constitution of the Republic of Indonesia is a written part of the basic law of our country. In the 1945 Constitution of the Republic of Indonesia, we can find out the national goals of our country which were formulated by the founding fathers, namely towards a just and prosperous society in a welfare state (welfarestate).

In order to achieve these national goals, hard work is needed by the Government (both at the central and regional levels) in exploiting all the existing potentials by observing the principle of sustainability. Because Indonesia is a constitutional state as stated in Article 1 paragraph (3) of the 1945 Constitution of the Republic of Indonesia, then of course the law will always occupy the main pioneer in regulating the life of the nation and state. Every matter relating to the livelihood of the public must be legitimized by the prevailing laws and regulations. This legitimacy is important in order to guarantee legal certainty and justice for the community.

In connection with this legitimacy, Article 18 paragraph (6) of the 1945 Constitution of the Republic of Indonesia also gives regional governments the right to stipulate regional 
regulations and other regulations to carry out autonomy and co-administration. So in order to implement autonomy, the regions have the right to stipulate regional regulations that regulate trading businesses.

\section{Law Number 5 of 1999 concerning Prohibition of Monopolistic Practices and Unfair Business Competition}

In current trading conditions, it is closely related to Law Number 5 of 1999 concerning the Prohibition of Monopolistic Practices and Unfair Business Competition, which in Article 1 Number 4 states that: "The dominant position is a situation in which a business actor has no significant competitors in the relevant market in relation to the controlled market share, or the business actor having the highest position among its competitors in the relevant market in terms of financial capacity, ability to access supply or sale, and ability to adjust the supply or demand for certain goods or services. "

In that article, the meaning of the sentence Competitor does not indicate a more concrete purpose and purpose than the meaning of the sentence itself. This sentence can lead to various understandings as well as various interpretations so that there is a need for an explanation of the sentence which is more than just a sentence "sufficiently clear" from the article by article explanation in the statutory regulation.

Article 2 stipulates that: "Business actors in Indonesia in carrying out their business activities shall be based on economic democracy by observing the balance between the interests of business actors and the public interest."

Furthermore, Article 3 also regulates the principles and objectives of the law, namely: "The objectives of the formation of this law are to: safeguard the public interest and increase the efficiency of the national economy as an effort to improve people's welfare; creating a conducive business climate by regulating healthy business competition so as to ensure certainty of equal business opportunities for large business actors, medium business actors and small business actors; prevent monopolistic practices and or unfair business competition caused by business actors; and creating effectiveness and efficiency in business activities. "

Articles 2 and 3 contain important substances regarding the meaning of economic democracy, namely the need to pay attention to the balance between the interests of business actors and the public interest, as well as the substance to increase economic efficiency and improve people's welfare.

Meanwhile Article 5 of Law Number 5 Year 1999 stipulates that "business actors are prohibited from entering into price fixing agreements with their competitors' businesses." This article prohibits price fixing agreements between business actors and competing business actors but does not prohibit price fixing agreements against business actors who are not competitors. This certainly creates its own legal loopholes, including in the retail business.

\section{Law Number 25 of 2007 concerning Investment}

The trading business grew and developed very fast, in line with the increase in population. This industry has also grown in popularity since the entry of modern trading businesses and owned by foreign investors in Indonesia. These entrepreneurs are competing to enter. From those who want to open branches (expand), set up new factories outside their home countries, look for strategic partners, to establish new companies. This is closely related to Law Number 25 of 2007 concerning Investment.

Article 1 Number 1 of Law Number 25 Year 2007 concerning Investment regulates that: "Investment is all forms of investment activities, both by domestic investors and foreign 
investors to conduct business in the territory of the Republic of Indonesia." Elucidation of Article 3 Paragraph (1) letter d Law Number 25 of 2007 concerning Investment also regulates that:

"What is meant by the principle of equal treatment and does not differentiate between countries of origin is the principle of non-discriminatory service treatment based on the provisions of laws and regulations, both between domestic investors and foreign investors as well as between investors from a foreign country and investors from a foreign country. other".

Article 1 Number 1 and Elucidation of Article 3 Paragraph (1) Letter d will direct Indonesia to economic liberalization. The principle of equal treatment that does not differentiate between countries of origin is the principle of Most-Favored Nations and National Treatment in the General Agreement Establishing the World Trade Organization. Meanwhile, according to the DPR, this principle refers to Law Number 29 of 1999 concerning Ratification of the International Convention on Elimination of All forms of Racial Discrimination 1965 by taking into account Law Number 5 of 1999 concerning Prohibition of Monopolistic Practices and Unfair Business Competition.

Article 3 Paragraph (2) regulates that: "The objectives of the implementation of investment include, among others: increasing national economic growth; creating jobs; promote sustainable economic development; increasing the competitiveness of the national business world; increase the capacity and capability of national technology;

to encourage the development of a people's economy; turning the potential economy into real economic strength by using funds originating from both domestic and foreign sources; and improve community welfare."

Article 1 Number 1 of Law Number 25 Year 2007 concerning Investment regulates that: "Investment is all forms of investment activities, both by domestic investors and foreign investors to conduct business in the territory of the Republic of Indonesia." Elucidation of Article 3 Paragraph (1) letter d Law Number 25 of 2007 concerning Investment also regulates that:

"What is meant by the principle of equal treatment and does not differentiate between countries of origin is the principle of non-discriminatory service treatment based on the provisions of laws and regulations, both between domestic investors and foreign investors as well as between investors from a foreign country and investors from a foreign country. other".

Article 1 Number 1 and Elucidation of Article 3 Paragraph (1) Letter d will direct Indonesia to economic liberalization. The principle of equal treatment that does not differentiate between countries of origin is the principle of Most-Favored Nations and National Treatment in the General Agreement Establishing the World Trade Organization. Meanwhile, according to the DPR, this principle refers to Law Number 29 of 1999 concerning Ratification of the International Convention on Elimination of All forms of Racial Discrimination 1965 by taking into account Law Number 5 of 1999 concerning Prohibition of Monopolistic Practices and Unfair Business Competition.

Article 3 Paragraph (2) regulates that: "The objectives of the implementation of investment include, among others: increasing national economic growth; creating jobs; promote sustainable economic development; increasing the competitiveness of the national business world; increase the capacity and capability of national technology;

to encourage the development of a people's economy; turning the potential economy into real economic strength by using funds originating from both domestic and foreign sources; and improve community welfare. " 
Article 3 Paragraph (2) Letter f reinforces the affirmation that capital activities in Indonesia, including the trading business, should prioritize social economic values as a whole, not only to owners of capital, both domestic and foreign owners of capital.

Article 4 stipulates that: "(1) The government establishes basic investment policies to: encourage the creation of a national business climate that is conducive to investment in order to strengthen the competitiveness of the national economy; and accelerate the increase in investment. (2) In stipulating the basic policy as referred to in paragraph (I), the Government: provides equal treatment for domestic investors and foreign investors with due observance of national interests ensuring legal certainty, business certainty and business security for investors since the process. processing of licensing until the end of investment activities in accordance with the provisions of laws and regulations; and open up opportunities for development and provide protection to micro, small, medium enterprises and cooperatives. (3) The basic policies as referred to in paragraph (1) and paragraph (2) are realized in the form of a General Investment Plan. " This article indicates the granting of privileges to foreign investors which is certainly contrary to Article 33 of the 1945 Constitution concerning the Indonesian Economic System.

Article 12 stipulates that: "(1) All business fields or types of business are open to investment activities, except for business fields or types of business which are declared closed and open with conditions. (2) Business fields closed to foreign investors are: a. production of weapons, ammunition, explosives, and war equipment; and b. business fields that are explicitly declared closed based on law. (3) The Government based on a Presidential Regulation shall determine business fields closed to investment, both foreign and domestic, based on the criteria of health, morals, culture, environment, national defense and security, as well as other national interests. (4) Criteria and requirements for closed and open business fields with requirements and a list of closed and open business fields with their respective requirements will be regulated by a Presidential Regulation. (5) The government determines open business fields with requirements based on criteria of national interest, namely protection of natural resources, protection, development of micro, small, medium enterprises and cooperatives, supervision of production and distribution, enhancement of technological capacity, participation of domestic capital, and cooperation with business entities appointed by the Government. " The provisions on closed and open business fields are classified based on Klasifikasi Buku Lapangan Usaha Indonesia (KBLI).

\section{Law Number 12 Year 2011 concerning the Establishment of Legislation}

As a consequence of the rule of law (rechtstaat) which adheres to the flow of positivism, it is obliged to carry out the development of national law that is carried out in a planned, integrated and sustainable manner in the national legal system which guarantees the protection of the rights and obligations of all Indonesian people based on the Constitution of the Republic of Indonesia 1945. For this reason, regulations are made regarding the formation of laws and regulations which are carried out in a definite, standardized and standardized manner and method that binds all institutions authorized to form statutory regulations in Law Number 12 of 2011.

In Law Number 12 of 2011 contains the principles for the formation of Legislation; type, hierarchy, and content of the Legislation; Planning Laws and Regulations; preparation of Legislation; statutory regulation drafting techniques; discussion and ratification of the Draft Law; discussion and stipulation of Draft Provincial Regulations and Draft District / City Regulations; the promulgation of Legislation; dissemination; 
public participation in the Formation of Legislation; and other provisions concerning the establishment of Presidential Decrees and other state and government institutions.

One of the important points that must be considered in drafting a regional regulation on public order is that the principles for the formation of laws and regulations and the principles of content material as mentioned in Article 5 and Article 6 of Law Number 12 of 2011 concerning the Formation of Laws and Regulations must be implemented. -invitation.

One of the important points that must be considered in drafting a regional regulation on public order is that it must apply the principles for the formation of laws and regulations and the principles of material content as mentioned in Article 5 and Article 6 of Law Number 12 of 2011 concerning the Formation of Laws and Regulations. -invitation.

Law Number 23 Year 2014 concerning Regional Government As Amended Several Times Recently With Law Number 9 Year 2015 Concerning the Second Amendment to Law Number 23 Year 2014 Concerning Regional Government

Local governments based on the law on regional government have concurrent powers (apart from absolute government affairs and general government affairs). This implies that the Regional Government has obtained the delegation of authority from the Central Government (except for the authority of foreign policy, defense and security, justice, national and religious monetary and fiscal, as well as Government Affairs which is the authority of the President as head of government).

The Law on Regional Government has distinguished Regional authorities consisting of Mandatory Government Affairs and Elective Government Affairs. Compulsory Government Affairs consists of Government Affairs related to Basic Services and Government Affairs that are not related to Basic Services. Compulsory Government Affairs related to Basic Services are Compulsory Government Affairs, some of which are basic services.

The Law on Regional Government has distinguished Regional authorities consisting of Mandatory Government Affairs and Elective Government Affairs. Compulsory Government Affairs consists of Government Affairs related to Basic Services and Government Affairs that are not related to Basic Services. Compulsory Government Affairs related to Basic Services are Compulsory Government Affairs, some of which are basic services.

Presidential Regulation Number 112 of 2007 concerning Structuring and Fostering Traditional Markets, Shopping Centers and Modern Stores

Trading business in relation to regulations based on Presidential Regulation No. 112/2007 concerning Structuring and Fostering Traditional Markets, Shopping Centers and Modern Stores, has several regulatory matters that deserve attention, including: Article 2 Paragraph (1) regulates that: Traditional must refer to the Regency / City Spatial Plan, and the Regency / City Spatial Layout Detailed Plan, including the Zoning Regulations. " In this case the central government delegates the authority regarding territoriality to the regional government.

The weakness of this article is that the Regional Spatial Planning regulations are often violated due to various interests. It is better if this article is directly regulated regarding which areas are prohibited from entering modern shops. In this regulation, there are rules regarding the distance between hypermarkets and traditional stores. However, it seems that the government has not taken a firm stance on how far should the distance between hypermarkets and traditional markets be. It only states that the establishment of modern 
shops must pay attention to the distance between hypermarkets and traditional markets that have existed before.

Article 8 provides that: "(1) Business cooperation between Suppliers and Wholesalers, Hypermarkets, Department Stores, Supermarkets, and Minimarket Network Managers is made by means of a written agreement in the Indonesian language and Indonesian law applies. (2) If in the business cooperation as referred to in paragraph (1) the terms of trade are regulated, then the trade terms are an integral part of the written agreement as referred to in paragraph (1).

In this law, the fees charged to suppliers are costs directly related to the supplier's product sales, such as regular discounts, fixed rebates, conditional rebates, promotional discounts, promotion budgets, distribution costs, listing fees. Then mentioned the imposition of a "reasonable" listing fee. In the content of this article, the compilers of the academic paper consider that the "fair" category does not have clear boundaries so that it has the potential for multiple interpretations according to the interests to be realized.

\section{CONCLUSION}

Trade is one of the pillars of the community's economy which contributes to economic growth in regions and countries. Trade is very important because trade is the main link directly to meet the needs of society.

Various regulations that have been promulgated by the government have not been able to accommodate the current conditions in trading businesses which are full of unfair business competition. This unhealthy business competition is indicated in the competition between entrepreneurs in various groups. Furthermore, if this unfair business competition is allowed to continue without the regulations governing it, the aim of the constitution to create social justice for all Indonesian people will not be achieved.

The presence of various regulations regarding trading business-related regulations, such as Law Number 5 of 1999 concerning Prohibition of Monopolistic Practices and Unfair Business Competition; Presidential Regulation Number 112 of 2007 concerning Structuring and Fostering Traditional Markets; and Regulation of the Minister of Trade Number 70 of 2013 concerning Guidelines for Structuring and Fostering Traditional Markets, actually provides a sufficiently adequate regulation but does not apply comprehensively to developments in the current era,

This Draft Regional Regulation was made to regulate competition between all layers of entrepreneurs in Serdang Bedagai Regency. The shift in the pattern of customer shopping behavior detected from a number of studies conducted shows that customer shopping activities are not only in an effort to meet the need for life necessities, but rather lead to the fulfillment of the need for recreation and relationships. A trading business actor who maintains a traditional trading business management, it is not possible to have a sustainable competitive advantage when faced with the increasing number of modern trading businesses that are managed with substantial capital or changes in consumer spending patterns which have consequences for changing their needs. against the existence of a business.

Currently, the gap between modern trading businesses and traditional trading businesses lies in the distribution chain that is digitally integrated in modern trading businesses, creating synergies among its users. Common standards allow information to flow more effectively between suppliers, modern entrepreneurs and banks to increase visibility, efficiency and process automation.

Meanwhile, traditional trading business entrepreneurs are usually cash based and have limited integration with suppliers or banks to manage purchases, supplies and payments. 
Without compatible technology, they benefit very little from the standards and infrastructure used by the larger businesses in this distribution chain. Business competition between modern trading entrepreneurs and traditional trading businesses is like fighting for something unbalanced. On the one hand, society needs a more modern economic life, namely through modern trading businesses, while on the other hand traditional trading businesses need to be maintained so that income and employment for entrepreneurs, both traditional trading businesses, continue.

Based on this condition, it is very necessary to form a regulation to create a balanced competition between traditional trading businesses and modern trading businesses, regulations that are able to bring justice to all entrepreneurs, not only provide protection for traditional trading businesses and forget about modern trading businesses that also have a very positive impact on the existence of the regional and national economy or vice versa. The regulation is in the form of a Trade Business Regional Regulation. This Regional Regulation is a norm or regulation made with the aim of realizing a sense of justice between modern trading businesses and traditional trading businesses, protecting domestic production, creating mutually synergistic competition, and reviving economic democratic values as emphasized in the precepts. The fourth is from Pancasila and has been clearly stated in the 1945 Constitution of the Republic of Indonesia Article 33 paragraph 1 which is beginning to disappear.

\section{REFERENCES}

Adri Poesoro. (2007). Pasar Tradisional di Era Persaingan Global”, Newsletter No. 22 April - Juni 2007.

Badan Pembinaan Hukum Nasional. (2014). Perencanaan Pembangunan Hukum Nasional 2015-2019, (Jakarta: Badan Pembinaan Hukum Nasional Kementerian Hukum dan HAM R.I, 2014).

Bambang Waluyo. (1996). Penelitian Hukum Dalam Praktek. Jakarta: Sinar Grafika.

Hamzah Halim dan Kemal Redindo Syahrul Putra. (2013). Cara Praktis Menyusun dan Merancang Peraturan Daerah; Suatu Kajian teoritis dan Praktek Empiris Disertai Manual, (Kencana, Jakarta.

Lawrence M. Friedman. (1984). American Law; An Introducing, (New York, W.W. Norton and Company.

Marzuki. Peranan Program Legislasi Daerah/Program Pembentuksan Peraturan Daerah Dalam Proses Pembentukan Peraturan Daerah.

Peter Mahmud Marzuki. (2010). Penelitian Hukum. Jakarta: Kencana.

Soerjono Soekanto. (1984). Pengantar Penelitian Hukum. Jakarta: UI-Press, 1984.

\section{Laws and Regulations}

Basic Law Number 5 of 1999 concerning Prohibition of Monopolistic Practices and Unfair Business Competition.

Law Number 20 of 2008 concerning Micro, Small and Medium Enterprises.

Law Number 12 Year 2011 concerning the Establishment of Legislation.

The 1945 Constitution of the Republic of Indonesia.

Presidential Regulation Number 112 of 2007 concerning Arrangement and Development of Traditional Markets, Shopping Centers and Modern Stores. 